5. Рикер П. Конфликт интерпретаций. Очерки о герменевтике. Пер. с фр., вступ. ст. и коммент. И. Вдовиной. Москва : Академический проект (Философские технологии), 2008. 695 с.

6. Сигал Э. Мастера советского камерного ансамбля Д. Ойстрах, Л. Оборин, С. Кнушевицкий. Одесса, 1979. 50 с.

7. Фромм Э. Человек для себя. Пер. с англ. А. Александровой. Москва : АСТ, 2017. 320 с.

\title{
REFERENCES
}

1. Bura, M. (2018) Lviv chamber and orchestral performance through the prism of the idea of personalism (the second half of XX - beginning of XXI century). Candidat's thesis. : [spec.] 17.00.03 "Musical art". Lviv, [in Ukrainian], 2018.

2. Iergiiev, I. (2016) Artistic universe of a musician-instrumentalist. Doctor's thesis. : [spec.] 17.00.03 "Musical art". Kyiv: NMAU imeni P.I. Chaikovskoho [in Ukrainian], 2016.

3. Ozhegov, S. (1960) Dictionary russian language. Moskow, [in Russian],1960.

4. Polskaya, I. (2001) Chamber ensemble: History, theory, aesthetics: monograph. Kharkiv: KhGAK, [in Ukrainian], 2001.

5. Ricoeur, P. (2008). The conflict of interpretations. Essays in Hermeneutics. (I. S. Vdovina, Trans). Moscow: Akademicheskiy Proekt [in Russian], 2008.

6. Sigal, E. (1979) Masters of the Soviet chamber ensemble D. Oistrakh, L. Oborin, S. Knushevytskyi. Odessa, [in Ukrainian],1979.

7. E. Fromm (2017) Man for himself. [Trans. from English A. Alexandrova]. Moscow: AST Publishing House, [in Russian], 2017.

УДК $78.03+782.1$

DOI https://doi.org/10.31723/2524-0447-2020-30-1-14

Свген Борисович Авраменко

ORCID: 0000-0002-3137-9477

здобувач кафедри історії музики та музичної етнографії

Одеської національної музичної академії імені А. В. Нежданової

avramenko.jenya1986@gmail.com

\section{ТЕМБР-АМПЛУА ЯК ІНСТРУМЕНТ ВИРАЖЕННЯ ОПЕРНОГО «ГОЛОСООБРАЗУ» (НА ПРИКЛАДІ ДРАМАТИЧНОГО ТЕНОРА)}

\begin{abstract}
Мета роботи - надати аналіз категорії «тембр-амплуа» в оперному мистецтві, обгрунтувати тембр-амплуа як інструмент сценічного вираження певного «голосообразу» у жанрі опери. Методологія дослідження: методологічною основою й інструментом дослідження є психологічний та музикознавчий аналіз особливостей жканрової комунікації, іманентного творчого процесу та технологічної вокальної специфіки драматичного тенора; для реалізації завдань дослідження застосовано компаративний аналіз специфіки творчого процесу народження сиенічного образу в оперного виконавия та драматичного актора. Наукова новизна полягає в тому, що вперше обгрунтовано значення тембру-амплуа певного типу голосу як комунікативного, психологічного та технологічного інструмента в реалізації художніх завдань загального тезауруса оперної вистави. Висновки. Тембр голосу співака є способом індивідуалізації та персоніфікації вокально-сценічного образу, тобто смислообраз народжується завдяки відповідному типу голосу. Тому типологія амплуа в опері грунтується на принципах експресивності та натуральності голосів, що є непрямим втіленням у вокальному мистецтві принципів реалістичного театру К.С. Станіславського - правдивість сценічного образу в опері визначається передусім відповідністю тембру-амплуа виконавия інтонаційній семантиці матеріалу. Тембр-амплуа - тип голосу, здатний у вокальному відображенні повноцінно виразити семантику характеру оперного персонажа. Тембр-амплуа «упредметнює» у вокальному звуиі тип особистості героя; спосіб його художнього мислення; особливості комунікації із глядачем; є втіленням технологічних особливостей звукоутворення певного типу голосу. Наголошується, що в опері, де не спрацьовують закони «сценічної маски» драматичного театру, втілення сиенічного образу є більш близьким до виконавських законів музиканта-інструменталіста (завжди «Я-дійсний», а не «Я-інший»). Тембр-амплуа «драматичний тенор», обраний для аналізу в даній статті, - це такий тип голосу, що здатний повноцінно виразити інтонаційну семантику смислообразу героя, який є центром драматургічного конфлікту опери.
\end{abstract}

Ключові слова: драматичний тенор, тембр-амплуа, «голосообраз», смислообраз.

(C) Авраменко E. Б., 2020 
Avramenko Yevhen Borysovych, Searching for the Department of Music History and Music Ethnography of the Odessa National A. V. Nezhdanova Academy of Music

Timbre as a tool for expressing operatic "voice" (on the example of a dramatic tenor)

Research objective is to provide an analysis of the category of timbre-role in opera, to substantiate timbre-role as a tool for the stage expression of a certain "voice" in the genre of opera. The methodology: psychological and musicological analysis of features of genre communication, immanent creative process and technological vocal specificity of dramatic tenor is the methodological basis and instrument of research; a comparative analysis of the specifics of the creative process of the birth of a stage image in an opera performer and a dramatic actor has been applied for the realization of the tasks of the research. The scientific novelty for the first time the importance of timbre-role of a certain type of voice as a communicative, psychological and technological instrument in the realization of artistic tasks of the general thesaurus of opera performance is substantiated. Conclusions. Singer's voice timbre is a way of individualizing and personalizing a vocalstage image, that is, a semantic image is born through an appropriate type of voice. Therefore, the typology of the role of opera in opera is based on the principles of expressiveness and naturalness of voices, which is an indirect embodiment in the vocal art of the principles of the K.S. Stanislavsky realistic theater - the veracity of the stage image in the opera is determined first of all by the correspondence of the performer timbre-role and intonational semantics of the material. Timbre-role - a type of voice that is able to fully express the semantic character of the opera character in the vocal reflection. The timbre-role determines the vocal expression of the character of the hero; the way of his artistic thinking; features of communication with the viewer; is an embodiment of the technological features of a particular type of voice. The timbre-role of the "dramatic tenor" is a type of voice capable of fully expressing the intonational semantics of the semantic image of the hero, who is the center of the dramatic conflict of opera.

Key words: dramatic tenor, timbre-role, "voice image", semantic image.

Авраменко Евгений Борисович, соискатель кафедры истории музыки и музыкальной этнографии Одесской национальной музыкальной академии имени А. В. Неждановой

Тембр-амплуа как инструмент выразительности оперного «голосообраза» (на примере драматического тенора)

Цель работы - проанализировать категорию «тембр-амплуа» в оперном искусстве, обосновать тембр-амплуа как инструмент сценического выражения определенного «голосообраза» в жанре оперы. Методология исследования: методологической основой и инструментом исследования является психологический и музыковедческий анализ особенностей жанровой коммуникации, имманентного творческого процесса и технологической вокальной специфики драматического тенора; для реализации задач исследования применен компаративный анализ специфики творческого процесса рождения сценического образа у оперного исполнителя и драматического актера. Научная новизна заключается в том, ито впервые обосновано значение тембра-амплуа определенного типа голоса как коммуникативного, психологического и технологического инструмента реализации художественных задач общего тезауруса оперного спектакля. Выводы. Тембр голоса певца является способом индивидуализации и персонификации вокально-сценического образа, т. е. смыслообраз рождается благодаря соответствующему типу голоса. Поэтому типология амплуа в опере основывается на принципах экспрессивности и натуральности голосов, что является опосредованным воплощением в вокальном искусстве приниипов реалистического театра К.С. Станиславского - правдивость сценического образа в опере определяется прежде всего соответствием тембра-амплуа исполнителя интонационной семантике материала. Тембр-амплуа - тип голоса, способный вокальными средствами выразить семантику характера оперного персонажа. Тембр-амплуа «опредмечивает» в вокальном звуке тип личности героя; способ его художественного мышления; особенности коммуникации со зрителем; является воплощением технологических особенностей звукообразования определенного типа голоса, подобно исполнительским законам музыканта-инструменталиста (всегда «Я-настоящий», а не «Я-другой»). Тембр-амплуа «драматический тенор», приведенный в качестве примера в данной статье, - тип голоса, способный полноценно выразить интонационную семантику смыслообраза героя, являющегося центром драматургического конфликта оперы.

Ключевые слова: драматический тенор, тембр-амплуа, «голосообраз», смыслообраз.

Актуальність теми дослідження. У широкому колі дослідницьких проблем виконавського, а саме оперного, мистецтва все більш актуальними стають питання докладного аналізу такої невловимої психологічної інстанції, як іманентний творчий процес. Отже, актуальне розуміння принципів взаємодії складових частин творчого процесу залежно від інструменту творчості. У цьому сенсі творчий процес, інструментом якого є живий голос співака, потребує більш докладного аналізу залежності умов, специфіки процесу та його результатів погляду художнього тезауруса оперної вистави та природи психологічної організації співака певного типу голосу.

Мета дослідження - надати аналіз категорії «тембр-амплуа» в оперному мистецтві, обгрунтувати тембр-амплуа як інструмент сценічного вираження певного «голосообразу» у жанрі опери. 
Наукова новизна. Уперше обгрунтовано значення тембру-амплуа певного типу голосу як комунікативного, психологічного та технологічного інструмента в реалізації художніх завдань загального тезауруса оперної вистави.

Виклад основного матеріалу. Тембр голосу - найбільш суттєве звукове відображення психологічної сутності людини взагалі та, звичайно, психологічної сутності співака, для якого концентрація на своєму голосі як центрі життєвих інтересів є однією із провідних особистісних характеристик.

На базі експериментальних досліджень В.Х. Маньоров дійшов висновку, що завдяки характеристикам голосу можна визначити такі аспекти особистості людини: вік; загальну манеру поведінки; інтелектуально-духовну зрілість; прояви темпераменту; спосіб мислення, ціннісні орієнтири [2, с. 51]. Отже, завдяки звучанню голосу можна описати не тільки фізичний стан людини, але й іiі психічний стан. Такої ж думки дотримується В.П. Морозов, який зазначає, що голос несе широченний асортимент інформації стосовно психофізичних якостей, станів та намірів [3].

Отже, можна припустити, що в оперному мистецтві певний тип голосу завжди є інструментом відображення певного «Голосообразу». «Голосообраз» розуміємо як реалізовану у вокальний спосіб сукупність індивідуальних психологічних характеристик, що виражають драматургічне навантаження персонажа. У цьому контексті «голосообраз», реалізація якого передбачає використання певного типу вокального голосу, потребує визначення й обгрунтування інструментарію вокального виконавського вираження.

Обгрунтування виконавського інструментарію оперного співака, на наш погляд, виходить із самої поетики опери як театрального жанру. Згідно з розумінням поетики за О.А. Потебнею, як зв'язку структури, форми та способу вираження художнього продукту, спробуємо пояснити інструментарій «голосообразу» в опері через специфіку народження, представлення та сприйняття глядачем сценічного персонажа.

Коло наших інтересів стосується аналізу взаємної зумовленості семантики образу та способів іiі вираження, притаманних саме оперному жанру. Інакше кажучи, яким чином, з огляду на специфіку оперної жанрової комунікації із глядачем, «голосообраз», як певний тип особистості музичного персонажа, визначає тембральні переваги типу голосу, необхідного для даної ролі-партії. Розглянемо цю проблему на прикладі драматичного тенора.

Який же «голосообраз» відповідає драматичному тенорові? Насамперед, згідно з висновками В.Х. Маньорова, це чоловік середнього віку - приблизно 30-40 років, який має сильну особистість; часто володар, хазяїн, людина, від якої залежать інші; має відпрацьовані часом та досвідом життєві орієнтири; здатний на вчинки; за типом темпераменту сильний пластичний тип (сангвінік, рідше холерик); за ціннісними орієнтирами - часто людина патетичного, героїчного складу або той, хто може вийти за межі загальноприйнятої соціальної поведінки (персонажі побутової драми - «Паяци», «Кармен»). Але завжди герой драматичного тенора - людина, здатна на широкий діапазон почуттів від ліричних до найбільш жорстких (найяскравіший приклад - «Отелло»).

Драматичні тенори використовуються композиторами для «озвучування» персонажів героїчного, трагічного характеру. Такий композиторський вибір зумовлений тип, що саме драматичний тенор як специфічний тип голосу здатен на тембральні тонкощі у відображенні переживань широкого діапазону саме в конфліктному, негативному аспекті.

Таке використання драматичного тенора має і своє біологічне пояснення: сила емісії звуку драматичного тенора та його тембральна забарвленість затребувані саме в образах, які перебувають, згідно з розумінням філософії К. Ясперса, у «межевій ситуації (нем. Die Grenzsituation) - смерть, страждання, боротьба тощо - те, що ставить людину на межу буття та небуття. Відповідно, для зображення сили переживань такого діапазону потрібен голос підвищеної сили та підвищеного драматизму. Із зазначеного можна зробити висновок, що в загальному розумінні «голосоообраз» в опері є смислообразом: тембральні характеристики голосу, призначеного для виконання певної партії, є визначальними у відображенні смислообразу в оперній виставі.

Треба зазначити, що в оперній виставі спосіб опанування авторської інформації виконавцем суттєво відрізняється від акторського алгоритму у традиційному розумінні. Отже, у драматичному мистецтві характер персонажа розкривається та пізнається когнітивними алгоритмами (які включають також підсвідомі механізми творчості), тобто через пізнання й усвідомлення; а в опері характер персонажв пізнається через відчуття - музичне враження від авторського матеріалу, тобто пізнається як інсайт, без рефлексії та логічного мислення, на рівні сприйняття не когнітивного, а архетипно-емоційного. Обставини дії, 
відносини між персонажами, характер самого героя формуються насамперед саме з музичних вражень співака, а не із драматургії твору. Співак здатний розшифровувати інтонаційний зміст навіть без слів, грунтуючись тільки на чутті, породженому мелодією, тональністю, гармонією, специфікою фактури тощо. Така специфіка сприйняття особистісних вражень непрямо пояснює й те, що в опері тип вокального голосу поділяється ще й за певним типом особистості героя: ліричний, драматичний, характерний. Такий «підтип» виокремлюється не тільки драматургічним навантаженням, технологічними вимогами для даної партії, але й типом інтонаційної семантики музичної мови вокальної партії. Отже, сприйняття співаком інтонаційної інформації та специфіка комунікації із глядачем теж деякою мірою залежать від типу голосу. Ще раз підкреслюємо, що процес не потребує когнітивного напруження. Самі інтонаційні архетипи музичного матеріалу вже програмують тип героя, спосіб дії героя, навіть тип розв’язання драматургічного конфлікту твору. Тому дуже важливою складовою частиною правильної передачі смислообразу глядачеві є саме тембр-амплуа певного персонажа.

В опері практично не трапляється відпрацювання образу у класичному акторському розумінні: немає «маски», є лише харизма співака, яка має різноманітне проявлення в різних мелодійних партитурах.

Акторський алгоритм співака, порівняно із драматичним актором, є досить простим та коротким (за винятком дуже рідких винятків із правила). Оперний співак не зайнятий формулюванням почуття, завдання, його аксіологічний апарат вельми обмежений. Таку специфіку вважаємо наслідком наявності у співака інших центрів сприйняття інформації інтонаційних (неформульовані). У театрі ж драматичному, навпаки, аксіологічний апарат актора є найважливішим інструментом творчого алгоритму, тому що, згідно із системою К.С. Станіславського, для включення позасвідомих механізмів творчості актор повинен відпрацювати всю свідому частину професійного алгоритму, яка передбачає насамперед чіткі формулювання: надзавдання персонажа, завдання в конкретній сцені, визначення «події» та інші технологічні етапи акторського процесу [6]. В оперному театрі закони відпрацювання сценічного образу мають дещо іншу основу: сама природа безперервної музичної течії не потребує формулювання, а тільки сприйняття та передачі почуттів глядачеві на рівні «я так відчуваю», а не «Я-інший». Саме тому закони акторського мистецтва в опері мають дещо іншу форму та зміст, вони спрямовані на найбільш повне освоєння «запропонованих обставин» саме особистістю співака, а не на формування зі співака іншої особистості - ролі-образу. Співак в опері $\boldsymbol{H E}$ перетворює свою особистість на особистість персонажа, в оперних виставах у виконавців ролей-партій практично відсутній ефект «маски» - «Я-іншого», виконавець завжди (за винятком, мабуть, опер-буфа) виступає як «Я у запропонованих обставинах». Таким чином, в опері сценічний образ - це не «театральна маска», а саме особистість співака «у запропонованих обставинах». А якщо не затребувана «маска» - перевтілення в іншу особистість, то діапазон виконавських амплуа звужується до кола героїв та героїнь психологічного театру К.С. Станіславського - тобто максимально наближеного до реальних характерів. А це спричиняє максимальну спорідненість типу особистості актора та типу його персонажа.

Але й тут поетика оперної вистави вступає в конфлікт із загальними законами театрального мистецтва. Будь-який сюжет на сцені - це розвиток подій. Сутність драматургії сценічного твору - відображення трансформації персонажа від первісного стану до нового, іншого стану розуміння себе та світу навколо себе, а шлях до цього розуміння - розвиток подій. Ключове слово будь-якого сценічного жанру, в основі якого лежить «лицедійство», «подія». Але специфіка оперної вистави полягає в тому, що розвиток сюжетної лінії відбувається поза межами головних художніх точок опери: ані арія, ані дует, ані ансамбль не $€$ «місцем події» у традиційному розумінні законів драматургічного розвитку. Будь-який музичний номер опери є радше осмисленням події героєм - дуже збільшеним, розтягненим у часі переживанням почуттів, викликаних подією. Зрештою, музичні номери опери навіть гальмують розвиток драматургічної дії, фокусують глядача на «застиглому» переживанні героя, зображеному та докладно розцвіченому з різних боків головним інструментом оперної комунікації - тембром голосу співака. А саме розвиток подій відбито в речитативних частинах, які є проміжними, перехідними пластами між музичними номерами опери - арією, дуетом, ансамблем. Отже, з погляду законів драматургії зображення розвитку подій в опері $€$ вельми специфічним. Головний акцент будь-якої оперної вистави закінчений музичний номер - арія, дует, ансамбль - саме така форма художнього продукту, що дозволяє фокусувати увагу глядача на солісті як головному виразникові поетики жанру. Саме музичний 
номер як «поле виразовості» вокальної творчості є головною центральною «подією» оперної вистави. У цьому контексті слово «подія» ми вживаємо для акцентування головної форми творчого вираження в жанрі. Отже, можна зробити висновок, що поетиці опери, як театрального жанру, притаманна акцентованість уваги не на вчинках героя, а на дуже збільшеному відображенні власних переживань героя - його рефлексії щодо вчинків.

Така специфічна художня форма вираження зумовлює і специфічний образ самого героя. На відміну від персонажа драматичної вистави, оперному герою непритаманна наявність другого-третього плану вираження. Трактування оперного героя завжди однозначне, шо задано специфікою художнього вираження вокаліста, - сприйняття та розуміння смислообразу закладено в «голосообразі»: легке сопрано - ліричний образ молодої дівчини; драматичне сопрано - драматичний образ, з акцентом на внутрішньому конфлікті; меццо-сопрано - персонаж первісно конфліктний, здатний на вчинок, часто віковий, рідше - характерний. Аналогічне ділення «голосообразів» стосується і чоловічих голосів. Інакше кажучи, для зображення певного типу персонажа майже єдиним інструментом є певний тип голосу (щасливий збіг зовнішності співака 3 його «голосообразом», на жаль, досить рідкісне явище). Отже, підтверджуємо, що смислове навантаження музичного образу - «голосообраз» (за законами драматичного мистецтва - амплуа) - відображено певним типом тембру.

Отже, тембр-амплуа, на наш погляд, - таке своєрідне тембральне «тавро», інструмент виразовості «голосообразу» в опері.

Логічним є припущення, що тембр-амплуа визначається й рамками «інтонаційних меж» музичного матеріалу: наприклад, для вираження емоцій страждання композитори використовують зовсім інші музичні побудови, інші гармонії та мелодичні оберти, ніж для вираження почуттів радості й щастя, причому не тільки у вокальній партії соліста, але й у загальній тембральній партитурі вистави.

Згідно з архетипною природою інтонаційного слуху (Д.К. Кірнарська) [1], у загальній музичній атмосфері вже закладено характер драматургічного конфлікту - комедія чи драма; навіть більше, емоційний ступінь цього конфлікту - драма чи трагедія. Тому вважаємо, що «інтонаційні межі» оперного образу завжди є визначеними, інакше кажучи, інтонаційна семантика ролі-партії - iї «голосообраз» - передбачає тип голосу (вужче, тембр-амплуа), що здатен повноцінно «упредметнити» смислове навантаження авторської партитури. На відміну від опери, у драматичному театрі немає жорстких «інтонаційних меж» образу, тому драматичні п’єси часто-густо є полем вельми парадоксальних трактувань авторського задуму.

Специфіка законів оперної вистави непрямо пояснює потужну особистісну енергетику, притаманну саме оперним співакам. На сцені вони виступають від себе, а не від «маски». У комунікації із глядачем оперний співак, на відміну від драматичного актора, не має можливості сховати свою людську сутність за «сценічною маскою», а амплуа героя, драматичного або ліричного, на відміну від характерного персонажа, передбачає потужну особистість виконавця. Людина-артист із кожним виходом на сцену випробується тисячною глядацькою залою, чого слабка людська особистість просто не витримає. Таке «протистояння» можливе тільки за умови рівності «опонентів» - глядача й артиста. Крім того, уже зазначалося, що музичні номери опери - це застигла емоція, відображення якої, розтягнене в часі, теж потребує неабиякої енергетики та сили особистості виконавця. Мабуть, непрямо це також пояснює те, що в оперній драматургії так мало образів характерних, оперний герой - це завжди особистість, їі позиція та смислове навантаження завжди мають чітке формулювання, а розвиток образу - завжди передбачену стратегію. До того ж творча особистість саме оперного співака не така вразлива як, скажімо, особистість драматичного актора ще й тому, що співак має постійне підсвідоме підтвердження своєї переваги - наявність голосу, його багатство, його інші професійні характеристики (тому конкурентність у цеху оперних співаків є досить малою, порівняно із драматичними акторами). Якщо Бог дав голос, співак уже захищений від певного кола конкурентних викликів. Драматичному актору ж кожного дня треба доводити свою спроможність, підтверджувати професійну репутацію. Співак же, маючи великий голос, не переймається певним колом навіть творчих проблем, а конкурентних і поготів (крім того, кожна партія має свій, чітко визначений тип голосу, що також значно звужує кількість конкурентів). Саме така специфіка жанру пояснює й особливості творчого процесу співака, специфіку його особистості.

Розглянемо сформульовані висновки на прикладі аналізу смислообразів тенора. Тенор герой сюжету (головна діюча особа чоловічої статі), але психологічне навантаження образу 
не є однаковим для ліричного та драматичного типів голосу. Як зазначено, кожен підвид типу голосу в опері трактується як амплуа героя (амплуа - це не тільки певне коло ролей, що відповідають даним актора, але й рід занять людини). Ліричний тенор - герой-коханець, романтичний герой, молода людина, образ думок якої спрямований на залагодження конфлікту, на згоду, на примирення, його ментальність гармонійна; драматичний тенор, навпаки, завжди фігура, навколо якої кристалізується конфлікт, його образ думок внутрішньо суперечливий, спосіб сприйняття викликів світу - страждання та спроба подолання внутрішнього конфлікту. Таке смислове навантаження у драматургії будь-якого сценічного твору несе завжди амплуа - драматичний, трагедійний герой. Композитори використовують тембр драматичного тенора для відображення саме такого типу амплуа, тому що саме такий тип голосу дає можливості втілити натуру неоднозначного, внутрішньо конфліктного персонажу, отже, амплуа героя в опері зможе бути втіленим тільки визначеним типом голосу, а ще вужче - певним вокальним тембром, який притаманний певному типу голосу.

Отже, грунтуючись на тому, що музичний матеріал ролі-партії передбачає передусім відповідність певному тембру-амплуа, розуміємо тембр-амплуа в опері як «упредметнену» у звуці психологічну характеристику персонажа.

3 огляду на зазначене, тембр-амплуа - тип голосу, здатний у вокальному відображсенні повноцінно виразити інтонаційну семантику характеру героя. Тембр-амплуа «упредметнює» у вокальному звуці тип особистості героя; спосіб його художнього мислення; особливості комунікації із глядачем; є втіленням технологічних особливостей звукоутворення певного типу голосу.

У західноєвропейській оперній традиції драматичний тенор - це завжди «двигун» подій сюжету, це образ вольового героя - у певному розумінні образ чоловічого в оперному мистецтві. У російській опері, згідно із традицією, герой із такими ж віковими та психологічними характеристиками - баритон. I тільки в «Піковій дамі» П.І. Чайковського - це драматичний тенор (майже єдиний випадок у російській класичній оперній традиціі). Недарма опера «Пікова дама» вважається вершиною драматургічної музичної майстерності П.І. Чайковського. На наш погляд, це такий певний сплав російської та західної оперної традиції у використанні тембру-амплуа, у смисловій семантиці певного типу оперного голосу. «Баритоновість» тембральних барв драматичного тенора надає високому чоловічому голосу «важкості», багаторівневості психологічних смислів, певної «героїчності» персонажу. У свою чергу, «теноровість» музичного матеріалу, що передбачає більш високе за теситурою звучання, більш дзвінкий тембр, який сам собою не заспокоює глядача, а навпаки, примушує його хвилюватися, - надає нервовості, загостреності, «оголеності» реакцій, відкриває цілу палітру барв цього амплуа, яку в даному разі можна порівняти з амплуа героя-неврастеніка у драматичному театрі. Такий герой завжди є не тільки центром подій, але й центром емоційних трансформацій усього твору, наприкінці - центром катарсичних переживань глядача.

Із цього виходить і специфіка сценічної комунікації драматичного тенора із глядачем. Персонаж, озвучений драматичним тенором, ніколи не «спілкується» із глядачем: у нього немає apart-реплік, його музичні номери ніколи не мають характеру представлення себе глядачеві, де в тексті арії представлені однозначні характеристики героя або його розповідь про себе, як, скажімо, монолог Водемона («Іоланта» П.І. Чайковського) або арія Рудольфа («Богема» Дж. Пуччіні). Також герой драматичного тенора ніколи не представлений у форматі гри, як, наприклад, Тріке («Євгеній Онєгін» П.І. Чайковського).

Монолог героя у виконанні драматичного тенора - це або внутрішній монолог (найяскравішими ілюстраціями такого монологу є аріозо Каніо з опери «Паяци» Р. Леонкавалло), або відкритий заклик до дії (стрета Манріко із «Трубадура» Дж. Верді). Якщо в ліричного тенора арія частіше представлена в семантиці інтонаційного архетипу прохання (ліричний архетип), у характерного тенора - архетипу гри, то у драматичного тенора нерідким $є$ переплетення в інтонаційній семантиці психологічної (отже, й інтонаційної) складової частини кількох архетипів як тембральне відображення складності та багаторівневості музичного персонажа [5, с. 158-164].

До речі, показовими для характеристики неоднозначної семантики музичного матеріалу, що передбачає тембр-амплуа «драматичний тенор», виступають арія Германа «Что наша жизнь? Игра! <...>» 3 «Пікової дами» П.I. Чаковського та арія Калафа "Nessun dorma” 3 «Турандот» Дж. Пуччіні. Хоча темп, насиченість партитури, семантика цих арій відповідають інтонаційному архетипу заклику, але психологічний аспект відображує звертання до самого себе - архетип медитації. Таке переплетення інтонаційних архетипів підтверджує притаманне саме персонажам драматичного тенора відображення внутрішньої конфліктності. Отже, можна передбачити, що драматичному тенорові - співаку притаманні й певні харак- 
теристики особистості: сильний тип нервової системи - що надає можливості переконливо втілювати на сцені переживання підвищеного градуса та розширеного діапазону.

Наголошуємо на тому, що в опері, де не спрацьовують закони «сценічної маски» драматичного театру, втілення сценічного образу є більш близьким до виконавських законів музиканта-інструменталіста, а саме:

- вибір репертуару завжди відповідає типу особистості виконавця, на відміну від театру драматичного, де «матеріал на спротив» (невідповідність амплуа актора та матеріалу ролі) активно використовується у втіленні драматичних творів на сцені;

- манера втілення музичного образу на сцені є відображенням психофізичного складника виконавця (сильний тип темпераменту втілює у виконавській інтерпретації тембральний діапазон, відмінний від слабкого типу темпераменту);

- певний вокальний матеріал передбачає визначений тип голосу. Навіть у камерному жанрі загальна музична фактура твору, теситура виконання, будування вокальної фрази донизу або догори - розраховані на строго визначений тип голосу. Але, якщо в камерному співі можливі й відхилення від стереотипів, то в оперному співі, де до вказаних характеристик авторського тексту додається ще й щільність оркестрової партитури та драматургічне навантаження образу, тип голосу є визначальним;

- музичний образ (інструментальний або оперний), на відміну від драматичного театру, це завжди «Я-дійсний», а не «Я-інший».

У цьому контексті зрозуміло специфіку оперного жанру як такого жанру сценічного виконавського мистецтва, де тип голосу - відповідний тип сприйняття навколишнього світу - ніколи не суперечить авторському музичному смислообразу. За висловом О.В. Наумова, в опері важливі питання: «що» - який образ планується створити на основі партитури, та «хто» - ідеальна модель артиста для цієї ролі, але немає питання «як» - амплуа оперної партії працює як «слухняний інструмент» у розкритті авторського задуму [4].

Наприклад, у жанрі опери Герман («Пікова дама» О.С. Пушкіна) не може трактуватися як ліричний герой (на відміну від драматичної вистави, де цей образ часто-густо трактують досить вільно - як слабку людину, як невдаху). Сам тип голосу Германа, який передбачав у своїй авторській партитурі П.І. Чайковський, зумовлює саме ні ліричні, а драматичні та трагічні прояви характеру персонажа. Навіть у ліричних сценах (наприклад, з Лізою) характер музики, інтервальна побудова, поліфонія вокальної лінії й оркестрової партитури в Германа передає не ліричність героя, а внутрішній конфлікт між ліричними почуттями героя та його природною психофізикою - загостреністю трагічного сприйняття, переваги переживань не гармонійного, а саме дисгармонійного характеру.

Саме із цих позицій можна аналізувати і специфіку інтонаційного сприйняття глядачем драматичного тенора як конфліктного смислообразу та, з іншого боку, спираючись саме на тембральні характеристики цього смислообразу, характеризувати драматичного тенора.

Висновки. Тембр голосу співака є способом індивідуалізації та персоніфікації вокальносценічного образу, тобто смислообраз народжується завдяки відповідному типу голосу. Тому типологія амплуа в опері грунтується на принципах експресивності та натуральності голосів [7, с. 37], що є непрямим втіленням у вокальному мистецтві принципів реалістичного театру К.С. Станіславського - правдивість сценічного образу в опері визначається передусім відповідністю тембру-амплуа виконавця інтонаційній семантиці матеріалу. Тембр-амплуа - тип голосу, здатний у вокальному відображенні повноцінно виразити семантику характеру оперного персонажа. Тембр-амплуа «упредметнює» у вокальному звуці тип особистості героя; спосіб його художнього мислення; особливості комунікації із глядачем; є втіленням технологічних особливостей звукоутворення певного типу голосу. Тембр-амплуа «драматичний тенор» - тип голосу, здатний повноцінно виразити інтонаційну семантику смислообразу героя, який є центром драматургічного конфлікту опери.

\section{СПИСОК ЛІТЕРАТУРИ}

1. Кирнарская Д.К. Психология специальных способностей. Музыкальные способности. Москва : Таланты - XXI век, 2004. 496 с.

2. Манёров В.Х. Психодиагностика личности по голосу и речи. Санкт-Петербург : Изд-во РГПУ им. А.И. Герцена, 1999. 96 с.

3. Морозов В.П. Искусство и наука общения : невербальная коммуникация. Москва : Изд-во ИПРАН, 1998. 164 с.

4. Наумов А.В. Понятие амплуа в практике оперного театра. $K$ постановке проблемы «Наука виера, сегодня, завтра» : материалы IV Международной заочной научно-практической конференции, 18 сентября 2013 р., Россия, Новосибирск. URL: https://sibas.info/conf/science/iv/33953 (дата звернення: 25.03.2020). 
5. Оганезова-Григоренко О.В. Автопоэзис артиста мюзикла как творческий феномен и предмет музыковедческого дискурса : монография. Одесса : Астропринт, 2019. 376 с.

6. Станиславский К.С. Работа актера над собой. Москва : Искусство. Ч. 1 : Работа над собой в творческом процессе переживания. Дневник ученика. 1985. 479 с.

7. Тан Чжанчен. Специфика трактовки баса в опере XVII-XIX веков: между амплуа и характером : дис. ... канд. искусст.: 17.00.03. Харьков, 2017. 216 с.

\title{
REFERENCES
}

1. Kyrnarskaya D. (2004) Psychology of special abilities. Musical abilities. M.: Talanty - XXI vek. [in Russian]

2. Manyorov V. (1999) Psychodiagnostics of personality by voice and speech. SPb. : Publishing House of the Russian State Pedagogical University named after A.I. Herzen. [in Russian]

3. Morozov V. (1998) The art and science of communication: non-verbal communication. M.: Publishing House IPRAN. [in Russian]

4. Naumov A. (2013) The concept of the role in the practice of the opera house. To the formulation of the problem "Science yesterday, today, tomorrow" // Proceedings of the IV International Correspondence Scientific and Practical Conference (September 18, 2013), Russia, Novosibirsk. [in Russian]

5. Ohanezova-Hryhorenko O. (2019) Autopoiesis of the musical artist as a creative phenomenon and the subject of musicological discourse. Odessa : Astroprint. [in Ukrainian]

6. Stanislavsky K. (1985) The actor's work on himself, part 1: Work on oneself in the creative process of experiencing. Student's diary. M. : Art. [in Russian]

7. Tan Chganchen (2017) The specifics of the interpretation of bass in the opera of the XVII-XIX centuries: between the role and character. Candidate degree of Arts: 17.00.03. Kharkov. [in Ukrainian]

УДК 78.03/.09+ [785:781.6]

DOI https://doi.org/10.31723/2524-0447-2020-30-1-15

\author{
Анна Владимировна Яцула \\ ORCID: 0000-0001-9517-4633 \\ магистрантка кафедры специального фортепиано, \\ фортепианно-теоретического и вокального факультета \\ Одесской национальной музыкальной академии имени А. В. Неждановой \\ yatsula.ann27@ukr.net
}

\section{ИСПОЛНИТЕЛЬСКИЙ СТИЛЬ Н. МЕТНЕРА В ИСТОРИКО-СТИЛЕВОМ КОНТЕКСТЕ МУЗЫКАЛЬНОЙ КУЛЬТУРЫ РУБЕЖА ХІХ-ХХ ВЕКОВ}

Цель работы - проанализировать исполнительский стиль Н. Метнера в историко-стилевом контексте. Для достижсения этой цели нами проанализирован путь Н. Метнера как пианиста, выделены основные компоненты его концертного репертуара. Отмечено, что на первом этапе становления Н. Метнера как пианиста репертуар состоял из произведений классиков и композиторов-романтиков, на последуюших этапах содержание репертуара могли составлять полностью авторские произведения или симбиоз (классические и авторские). Методология исследования базируется на историко-аналитическом методе. Используются хронологический и текстологический подходы, предполагающие опору на конкретный фактический и стилистический материал, последовательные сравнения и обобщения. На основе анализа стилевых особенностей игры Н. Метнера обнаруживается, что для Н. Метнера-пианиста характерен определенный «исполнительский идеал», который проявляется в эмоциональной сдержанности, мастерстве владения художественными и техническими средствами игры на фортепиано. Н. Метнер как пианист всегда стремился к ясности изложения музыкальной мысли. Основой всего структурного построения является тема, ее развертывание, проникновенность и глубина звучания. Особенностью тематизма является фактурное наслоении тем, где каждая выполняет свою задачу, с одной стороны, развивается своим особенным путем, с другой - является частью иелого. Для композитора-исполнителя нехарактерны импульсивность, пафосность, излишняя откровенность чувств и эмоций. Метнеровская проникновенность, элегичность, задумчивость всегда имеет индивидуальный смысловой стержень, концепционную завершенность. Научная новизна - определение историко-стилевых особенностей исполнительской интерпретации Н. Метнером собственных произведений. Доказывается, что обстоятельства судьбы композитора стали предпосылкой его самобытного музыкального 